\title{
CHECKLIST FOR THE INTRAHOSPITAL TRANSPORT OF PATIENTS ADMITTED TO THE INTENSIVE CARE UNIT
}

\author{
Renata da Silva ${ }^{1}$ Lúcia Nazareth Amante ${ }^{2}$
}

\footnotetext{
${ }^{1}$ M.Sc. in Nursing. RN of the Intensive Care Unit of the Teaching Hospital of Uberlândia. Uberlândia, Minas Gerais, Brazil. E-mail: renatadasilvasantana@ig.com.br

${ }^{2}$ Ph.D. in Nursing. Adjunct Professor of the Department of Nursing and of the Postgraduate Program in Nursing of the Universidade Federal de Santa Catarina. Florianópolis, Santa Catarina, Brazil. E-mail: lucia.amante@ufsc.br
}

\begin{abstract}
Checklists represent a simple tool incorporating barriers for protecting patient safety. The objective was to develop a script for patient evaluation for the intrahospital transport of patients admitted to the Intensive Care Unit of a hospital in the Triângulo Mineiro region, based on two strategies. The first: a descriptive, prospective and quantitative study; the second: integrative research, undertaken in four databases. It was ascertained that the incidents are related to breakdowns and problems related to poor functioning in equipment and devices, with adverse events being frequent involving variation in blood pressure, agitation, drops in peripheral arterial saturation and tachycardia. Emphasis is also placed on the need to verify the effectiveness of the present script for patient evaluation for intrahospital transport in relation to patient safety, and its level of practicality through its use in the varying hospital spaces, such that the same may become a checklist.
\end{abstract}

DESCRIPTORS: Nursing. Checklist. Patient transport. Intensive care unit.

\section{CHECKLIST PARA O TRANSPORTE INTRA-HOSPITALAR DE PACIENTES INTERNADOS NA UNIDADE DE TERAPIA INTENSIVA}

RESUMO: O checklist representa uma ferramenta simples que incorpora barreiras de proteção para a segurança do paciente. O objetivo foi elaborar um roteiro para avaliação do paciente para o transporte intra-hospitalar de pacientes internados na Unidade de Terapia Intensiva de um hospital da região do Triângulo Mineiro, a partir de duas estratégias. A primeira: estudo descritivo, prospectivo, quantitativo; e a segunda: pesquisa integrativa, realizada em quatro bases de dados. Verificou-se que os incidentes estão relacionados a panes e problemas de mau funcionamento nos equipamentos e dispositivos, sendo eventos adversos frequentes a variação da pressão arterial, a agitação, a queda da saturação arterial periférica e a taquicardia. Ressalta-se, ainda, a necessidade de verificar a efetividade do presente roteiro para avaliação de paciente para transporte intra-hospitalar para a segurança do paciente e qual seu nível de praticidade por meio de sua utilização nos diversos espaços hospitalares, a fim de que o mesmo se torne um checklist.

DESCRITORES: Enfermagem. Checklist. Transporte de pacientes. Unidade de terapia intensiva.

\section{CHECKLIST PARA EL TRANSPORTE INTRAHOSPITALARIO DE PACIENTES INTERNADOS EN UNA UNIDAD DE TERAPIA INTENSIVA}

RESUMEN: El Checklist representa una herramienta sencilla que introduce barreras de protección para la seguridad del paciente. El objetivo fue crear un guión de evaluación para el transporte intrahospitalario de los pacientes internados en la Unidad de Terapia Intensiva de un hospital en la región del Triangulo Mineiro a partir de un estudio descriptivo, prospectivo y cuantitativo y de una investigación integrada realizada en cuatro bases de datos. Fue comprobado que los incidentes están relacionados con problemas de mal funcionamiento de los equipos y las adversidades más frecuentes fueron la variación de la presión arterial, la agitación psicomotora, la disminución de la saturación arterial periférica y taquicardia. Resaltamos todavía la necesidad de investigar la efectividad del presente guión para la evaluación del paciente para el transporte intrahospitalario para garantizar su seguridad y cuál es el nivel de practicidad en su utilización en los hospitales para que él se torne un Checklist.

DESCRIPTORES: Enfermería. Checklist. Transporte de pacientes. Unidad de terapia intensiva. 


\section{INTRODUCTION}

Worldwide, millions of patients each year suffer incapacitating harm, prolonging of their stay in hospital, or death, resulting from unsafe healthcare. ${ }^{1}$ Based on the principle that patients should not suffer harm, patient safety has been increasingly recognized in all countries as an issue of global importance, given that the process of healthcare contains a certain degree of inherent unsafety. ${ }^{2}$ The general perception of patient safety is a dimension of results, and indicates the existence of processes and systems for preventing errors and patient safety problems. ${ }^{3}$

Patient safety results from reducing avoidable risks and harm during the process of healthcare to an acceptable minimum. ${ }^{1}$ Being aware of the frequency, causes and nature of the occurrence of incidents and adverse events (AEs) makes it possible to develop strategies which minimize the harm resulting from the care provided, and the unnecessary suffering of the patient and of the team which provided the care.

The incident is an event or circumstance which could have resulted, or which resulted, in unnecessary harm to the patient. The incident always has a set of contributing factors, and does not necessarily need to have caused harm to the patient, but is a circumstance which has the potential for this. ${ }^{4-5}$ The adverse event (AE) is an unwanted complication or a non-intentional injury resulting from the health care, which caused harm to the patient. ${ }^{6}$ For this study, the following were defined as incidents: disconnection, displacement, occlusion, loss, traction of devices, accidental extubation, battery failure, oxygen running out, and poor functioning of equipment. Also categorized for this study as AEs were: systemic arterial hypertension, systemic arterial hypotension, tachycardia, bradycardia, tachypnea, bradypnea, apnea, drops in oxygen saturation levels, cardiac arrest, arrhythmias, agitation, falls, bleeding and death. ${ }^{9-10}$

It is known that inappropriate care makes the patients the victims of complications, with the Intensive Care Unit (ICU) being one of the places which most compromises patient safety. ${ }^{7}$ ICU is an environment full of technological resources which assist in the attempt to preserve the patient's life, and which provide the professionals with greater control over situations of risk, as well as helping to guide treatment and detect unwanted complications. However, difficulties are still found in this environment for undertaking certain examinations and procedures which cannot be undertaken at the bedside, because the technological apparatus are not portable and are located in areas outside ICU. In this regard, intrahospital transport (IHT) becomes essential and necessary. ${ }^{8-9}$

The options for diagnostic and/or therapeutic interventions have led to the growing transfer of patients from ICU to other departments, such as the imaging department and the surgical center (SC). The movement of patients from ICU is a frequent activity and has the potential for incidents and AEs related to equipment, patient care, communication and planning. As a result, the risks and benefits of transferring a patient must be taken into consideration, including an evaluation of the patient's clinical status prior to transport, of the benefits of this transport for the patient, of the team which will accompany the patient and of the equipment available. ${ }^{10}$ Among the interventions possible for preventing incidents and AEs, the checklist has been one instrument available for assisting in the planning of the transport, and in reducing AEs. ${ }^{11}$

In the area of health, the checklist was launched by the WHO, initially being implemented in surgical centers, showing a reduction of complications from $11 \%$ to $7 \%$ following its introduction. ${ }^{12}$ The strategy for using a checklist was also presented as a method of intervention for reducing the AEs during the IHT of patients from the emergency department. ${ }^{13}$ In general, AEs reduced significantly from $36.8 \%$ prior to the intervention, to $22.1 \%$ in the post-intervention period, it being concluded that the use of the checklist for IHT reduces the rates of AEs. ${ }^{13}$ As a result, it is understood to be an instrument which is applicable and efficient for IHT.

Checklists have the potential to improve the safety and quality of care provided to patients in the health services, and to reduce costs in ICU. They facilitate the application of complex tasks, reduce the variability, improve communication within the team and help to guarantee that everything that needs to be done actually is done. ${ }^{14}$ By contrast, there are still few studies offering the choice to use this tool in clinical practice as a means of improving safety in IHT. ${ }^{15}$

In the context of the ICU studied, IHT is undertaken by the ICU team itself, during the service's three shifts, always being accompanied by a minimum of two professionals. The minimum equipment necessary, when remembered at the time of planning, which accompany the patient during the transport are: the bag valve mask 
(ambu bag), the pulse oximeter, the oxygen cylinder, the stethoscope, the sphygmomanometer, the emergency bag (containing materials and drugs for emergency attendance in the imminence of an incident or $\mathrm{AE}$ ), and the transportation ventilator (TV). In the ICU department there is no document standardizing the IHT process, and aiming to minimize the occurrence of incidents and AEs.

In this regard, it is recommendable that a script should be organized with the aim of promoting safety and improving complications resulting from IHT. This script could be in the form of a checklist and must be a process of continuous vigilance, in order to identify potential risks, allow better communication within the team, and direct efforts in order to implement better practices for safer care related to IHT. The research question of the present study was: what are the elements necessary for a patient evaluation script for the intrahospital transport of patients admitted to the ICU of a hospital in the region of Triângulo Mineiro? It aimed to develop a script for evaluating the patient for intrahospital transport of patients admitted to the ICU of a hospital in the Triângulo Mineiro region.

\section{METHOD}

Two strategies were used in order to develop the script for evaluating patients for intrahospital transport. The first strategy was the undertaking of a descriptive, quantitative study, undertaken in the ICU of a teaching hospital in the Triângulo Mineiro region, undertaken between $11^{\text {th }}$ February 2013 and $10^{\text {th }}$ May 2013. A total of 103 transports were monitored, which represented the inclusion of 70 patients and 100 professionals, bearing in mind that each transport was accompanied by at least two professionals from the ICU team. The following inclusion criteria were considered: the IHT of the patient over 18 years old, admitted to ICU, who required IHT in order to undertake an examination in the propaedeutics (physical area set aside for imaging examinations), the presence of the professionals who undertook the IHT during the transfer (both going and returning) and the undertaking of the examination, leaving and returning to the ICU, and being accompanied by professionals allocated to ICU or who were on placement during the data collection. IHTs of patients who undertook more than one examination during the same transfer were excluded.

The method used for data collection was nonparticipant observation with the application of an instrument titled "Observation script". This script is made up of two parts: in the first, the patient's data (the initials of the patient's name, the date of the examination, age, sex and medical diagnosis); the second contains the data collected during the preparation, move and return of the patient who underwent the IHT (related to the patient's clinical condition, the purpose of the examination, the professionals involved, the presence of devices, drugs and equipment used during the transport, the duration of the transport, and occurrence of AEs). It was validated by a pilot test administered during 16 IHT. The participants' identities and rights were preserved, in accordance with Resolution n. 466/2012, of the National Health Council. The project was authorized by the participating institution and was approved by the Research Ethics Committee of the Universidade Federal de Santa Catarina, under protocol n. 154.992, CAAE 11026912900000121.

The data obtained were subjected to descriptive, inferential and analytical analysis, through the total of responses, the percentage, and the confidence interval of $95 \%$ for each item of the questionnaire, or through measurements of central tendency and variation. In order to undertake the statistical analyses, the normality and homoscedasticity of the untransformed noncategorical data were initially tested, using the Shapiro-Wilk and Levene tests, respectively. ${ }^{16-17}$ Subsequently, in accordance with the results of these tests, the Wilcoxon, Kruskall-Wallis, Anova and Tukey statistical tests were used, adopting a level of significance of $p \leq 0.05$. The analyses were undertaken using the R 3.0.1 program. ${ }^{18}$

All the patients, or those responsible for them, the professionals and the interns who manifested their agreement to participate in the study signed the terms of free and informed consent.

The second strategy was the undertaking of an integrative review, undertaken between the $19^{\text {th }}$ and $22^{\text {nd }}$ of July 2013, which followed six stages. In the first two stages, the reason for the research and the research question which would be this study's axis were defined. The question established was: what was the production regarding the safety of the seriously-ill patient and intrahospital transport, related to the nursing care, in the period 2003 - 2013, through an integrative review in nursing studies? In the third stage, the following databases were determined: Scientific Electronic Library online (SCIELO), the Base de Dados em Enfermagem (Nursing Database) (BDENF), the Latin American 
and Caribbean Health Sciences Literature database (LILACS) and Medical Literature Analysis and Retrieval System Online (MEDLINE). In the fourth stage, the inclusion and exclusion criteria for the IHT were determined. The inclusion criteria were: to be scientific articles, available in full, online, in the Portuguese, English or Spanish languages, published between January 2003 and June 2013, containing title, abstract, the following descriptors or keywords: intrahospital transport, patient safety, seriously-ill adult patients, and intensive care unit; and to be related to the nursing care. Scientific articles were excluded if they were: published outside the collection period, duplicated, not available in full, were theses or dissertations from other areas of knowledge, or were about seriously-ill patients who were not adults. In the fifth and sixth phases, the data were presented and evaluated respectively. In order to record the data, a script was used, which presents the reference of the articles, the type of study, the locale, variables, sample, source of the data, statistical tests, discoveries, recommendations, and strong and weak points. ${ }^{19}$ The analysis was undertaken critically, seeking to explain the results of the different studies.

\section{PRESENTATION OF THE RESULTS AND ANALYSIS}

The results will be presented in three stages: the first stage will report the results of the application of the observation script, the second will describe the findings of the integrative research, and the third will present the script for evaluation of patients for intrahospital transport.

First stage: nonparticipant observation of the intrahospital transport

The results of the use of the "Observation script" reveal that the same identified the incidents and the AEs. The incidents which occurred were due to the equipment and devices. These included one disconnection and one loss with invasive arterial catheters, two tractions with the oxygen catheter, one loss of a central venous catheter and one loss of a peripheral venous catheter, one disconnection and one traction with an indwelling catheter. The following occurred with the equipment: on one occasion, the battery of a continuous infusion pump failed, on one occasion an oxygen cylinder emptied, a pulse oximeter malfunction occurred once and the batteries of pulse oximeters failed on seven occasions. The most frequent AEs were: hypertension $(8.9 \%)$, followed by hypotension $(4.9 \%)$, and agitation, a drop in peripheral arterial saturation, hypertension and tachycardia, with $2.9 \%$ of the cases each.

It is emphasized that, in their turn, the patient's seriousness and clinical conditions indicate the number of people who will participate in the transport..$^{20}$ The transport of the patient from the unit to which she was admitted to other areas of the hospital environment constitutes a challenge for the health professionals involved in this task, due to the seriousness of the patient and to the complications to which this patient is exposed during the transport.

\section{Second stage: integrative review}

Of the 2,685 articles found, 115 were selected, of which 65 were repeated in one or more databases; thus, 50 articles remained. Of these 50 articles, 45 did not respond to the research question or were not focused on nursing; thus, five articles remained for analysis.

Table 1 presents the articles selected in accordance with objective, method and results.

Table 1 - Distribution of the articles according to objective, method and results. Florianópolis, State of Santa Catarina

\begin{tabular}{|c|l|l|l|l|}
\hline Order & \multicolumn{1}{|c|}{ Reference } & \multicolumn{1}{c|}{ Objective } & \multicolumn{1}{c|}{ Method } & \multicolumn{1}{c|}{ Results } \\
\hline $\mathbf{1}$ & $\begin{array}{l}\text { Chang, Y, Lin LH, Chen WH, } \\
\text { Liao HY, Hu PH, Chen SF, et } \\
\text { al. Quality control work group } \\
\text { focusing on practical guide- } \\
\text { lines for improving safety of } \\
\text { critically ill patient transporta- } \\
\text { tion in the emergency depart- } \\
\text { ment. J Emerg Nurs. 2010 Mar; } \\
\text { 36(2):140-5. }\end{array}$ & $\begin{array}{l}\text { To establish guidelines } \\
\text { for intrahospital trans- } \\
\text { port }\end{array}$ & $\begin{array}{l}\text { Circle of qual- } \\
\text { ity method }\end{array}$ & $\begin{array}{l}\text { Elaboration of strategies } \\
\text { through the composition } \\
\text { of the group of profession- } \\
\text { als which improved safety } \\
\text { during the intrahospital } \\
\text { transport of seriously-ill } \\
\text { patients through educational } \\
\text { programs and the provision } \\
\text { of better quality care. }\end{array}$ \\
\hline
\end{tabular}




\begin{tabular}{|c|c|c|c|c|}
\hline Order & Reference & Objective & Method & \begin{tabular}{|c|} 
Results \\
\end{tabular} \\
\hline 2 & $\begin{array}{l}\text { Nogueira VO, Marin HF, } \\
\text { Cunha ICKO. Informações } \\
\text { on-line sobre transporte intra- } \\
\text { hospitalar de pacientes críticos } \\
\text { adultos. Acta Paul Enferm. } \\
\text { 2005; 4(18):390-6. }\end{array}$ & $\begin{array}{l}\text { To develop an educa- } \\
\text { tional page on the World } \\
\text { Wide Web, providing } \\
\text { and representing infor- } \\
\text { mation relevant to con- } \\
\text { tinuous education in the } \\
\text { intrahospital transport of } \\
\text { critically-ill patients }\end{array}$ & $\begin{array}{l}\text { Trochim } \\
\text { method }\end{array}$ & $\begin{array}{l}\text { Elaboration of a website and } \\
\text { a protocol for conduct for } \\
\text { the intrahospital transport of } \\
\text { critically-ill patients. }\end{array}$ \\
\hline 3 & $\begin{array}{l}\text { Jarden RJ, Quirke S. Improv- } \\
\text { ing safety and documentation } \\
\text { in intrahospital transport: } \\
\text { development of an intrahospi- } \\
\text { tal transport tool for critically } \\
\text { ill patients. Intensive Crit Care } \\
\text { Nurs. } 2010 \text { Apr; 26(2):101-7. }\end{array}$ & $\begin{array}{l}\text { To develop a tool for the } \\
\text { intrahospital transport of } \\
\text { seriously-ill patients }\end{array}$ & $\begin{array}{l}\text { Literature } \\
\text { review }\end{array}$ & $\begin{array}{l}\text { Elaboration of a tool for as- } \\
\text { sisting during the intrahospi- } \\
\text { tal transport. }\end{array}$ \\
\hline 4 & $\begin{array}{l}\text { Almeida ACG, Neves ALD, } \\
\text { Souza LBC, Garcia JH, Lopes } \\
\text { JL, Barros ALBL. Transporte } \\
\text { intrahospitalar de pacientes } \\
\text { adultos em estado crítico: } \\
\text { complicações relacionadas } \\
\text { à equipe, equipamentos e } \\
\text { fatores fisiológicos. Acta Paul } \\
\text { Enferm. 2012; 25(3):471-6. }\end{array}$ & $\begin{array}{l}\text { To identify in the litera- } \\
\text { ture the complications } \\
\text { related to the patient's } \\
\text { physiological changes, } \\
\text { to the multidisciplinary } \\
\text { team, and to the use of } \\
\text { equipment during the } \\
\text { intrahospital transport of } \\
\text { critically-ill patients }\end{array}$ & $\begin{array}{l}\text { Literature } \\
\text { review }\end{array}$ & $\begin{array}{l}\text { The events encountered most } \\
\text { were: physiological changes } \\
\text { of the patient, problems in } \\
\text { the multidisciplinary team } \\
\text { involved in the transport and } \\
\text { in the inter-team commu- } \\
\text { nication, and failures in the } \\
\text { equipment. }\end{array}$ \\
\hline 5 & $\begin{array}{l}\text { MacLenon M. Use of a } \\
\text { specialized transport team } \\
\text { for intrahospital transport of } \\
\text { critically } 111 \text { patients. Dimens } \\
\text { Crit Care Nurs. } 2004 \text { Sept-Oct; } \\
\text { 23(5):225-9. }\end{array}$ & $\begin{array}{l}\text { To identify in the litera- } \\
\text { ture the adverse events } \\
\text { during intrahospital } \\
\text { transport and to identify } \\
\text { the benefits of a special- } \\
\text { ized transport team }\end{array}$ & $\begin{array}{l}\text { Literature } \\
\text { review }\end{array}$ & $\begin{array}{l}\text { Results favorable for patient } \\
\text { safety through the creation of } \\
\text { specialized transport teams. }\end{array}$ \\
\hline
\end{tabular}

Of the articles selected for the integrative review, only one was semi-experimental and demonstrated that IHT has potential for incidents and AEs, bearing in mind the disconnection of devices. ${ }^{21}$ The same study identified four safety indicators for IHT: respiratory apparatus, circulatory apparatus, equipment and duration of the transport. Furthermore, the circle of quality was applied as a method for organizing and implementing a guideline for the safe IHT of patients from the emergency service. After the implementation of the guideline and the training of the professional team, it was ascertained that there was an improvement in the quality of the services, through the planning of the transport, the evaluation of the patient and equipment, and the minimization of the risks through the reduction of the incidents and AEs. ${ }^{21}$

Another article was an applied study, which aimed to develop an educational page on the World Wide Web, providing information on IHT of adult ICU patients, whose content was evaluated by specialists and which proposed a protocol for conducts for the undertaking of IHT. The website was evaluated as relevant, informative, easy to use and possessing excellent content, and contributed to the dissemination of information and assistance in training and improvement programs. The protocol of conducts was elaborated in the three axes, namely: evaluation of the patient's clinical conditions, composition, scientific knowledge and training of the team which undertook the IHT, and evaluation of the equipment and materials which formed part of the transport. ${ }^{22}$

The remaining articles - three - were literature reviews, which indicated that the most common AEs were related to two aspects: one related to the equipment, and the other to the patients. The problems with the equipment included disconnection, loss of intravenous access, the oxygen supply finishing, and equipment failures. The problems with the patients involved hypotension, arrhythmias, hypoxia, and increase in intracranial pressure. ${ }^{15,23-24}$

One of the studies recommends that IHT should be undertaken by a specialized team. This team requires scientific knowledge and administrative and financial support. ${ }^{23}$ The studies also emphasized that the evaluation of the patient, the use of protocols and guidelines for IHT, and evaluation of equipment and communication among transport team members are fundamental. 
Third stage: organization of the script for evaluation of the patient for intrahospital transport

Based in this theoretical and practical scenario, the script for evaluation of the patient for intrahospital transport was constructed considering the following items: identification of the patient, the tests requested, communication between departments, destination, professionals involved, pre-transport evaluation of the respiratory, circulatory, neurological, metabolic, digestive, genitourinary systems, drug therapy and equipment, evaluation during intrahospital transport (monitoring of vital signs, control of equipment and their functioning, and changes in the infusion of vasoactive drugs) and evaluation of the return of the intrahospital transport.

The checklist was divided into four stages: identification of the patient, evaluation pre-IHT (of the respiratory, circulatory, neurological, metabolic, digestive and genitourinary systems, vasoactive and sedative drugs, equipment), evaluation during the IHT (covering the patient's clinical conditions, devices, equipment and drugs) and evaluation in the return of the IHT (covering the patient's clinical conditions, devices, equipment, drugs and recording of the transport). As a result, this instrument can assist with all the stages related to the IHT and serve as an alert for the prevention of incidents and AEs, so as to promote safer care on the part of the team involved in the IHT. The script is presented below.

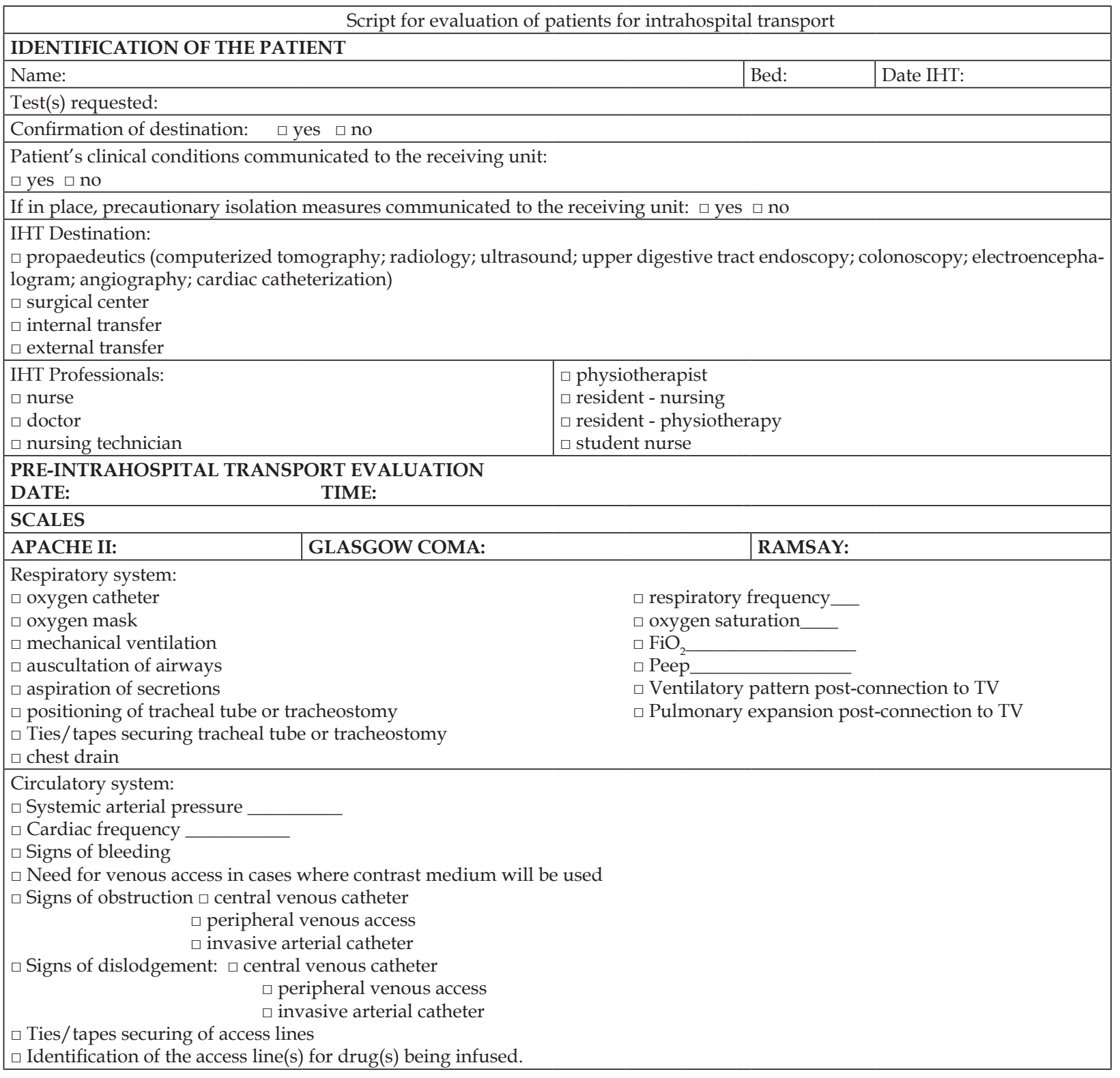




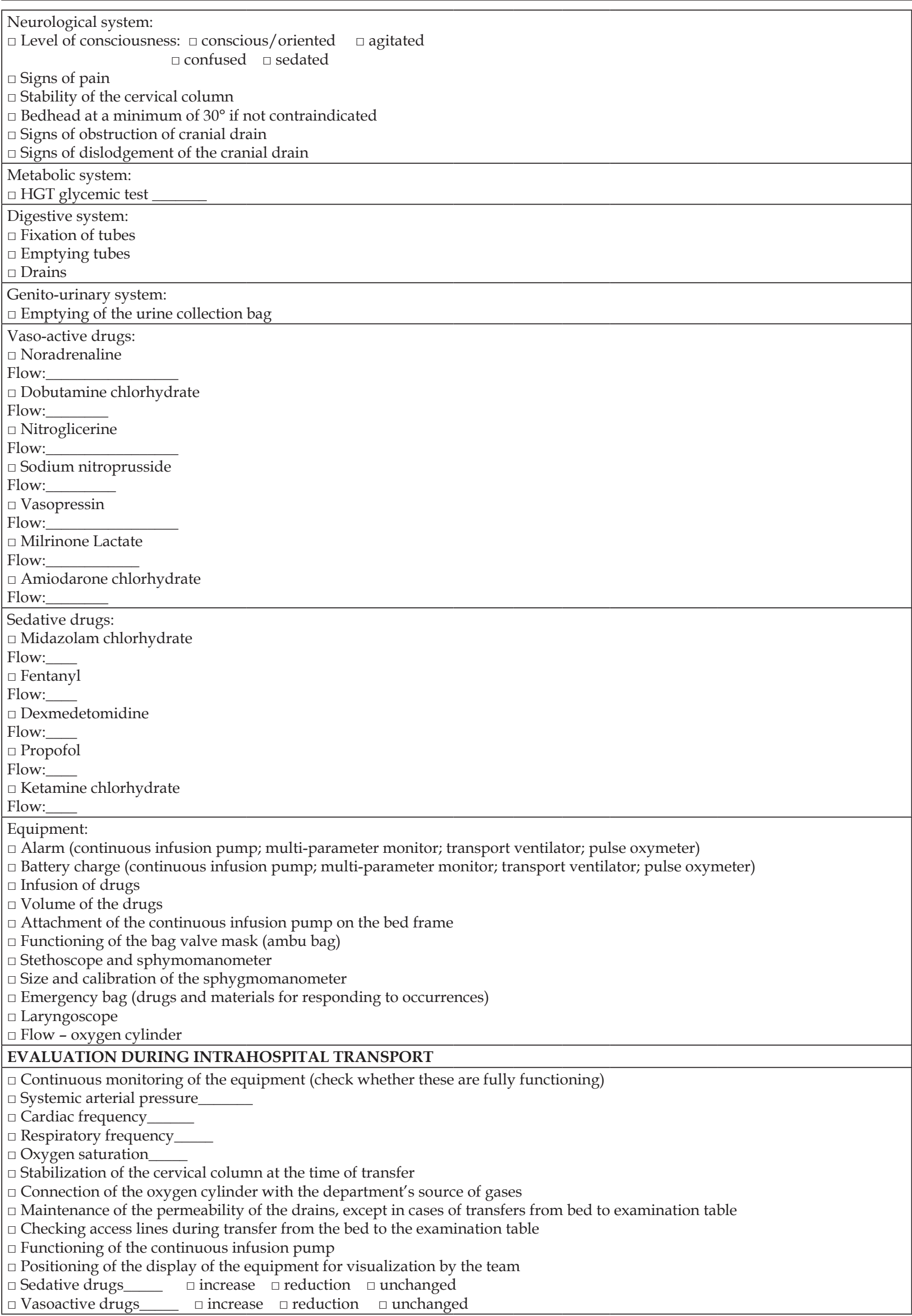




\section{EVALUATION OF THE RETURN OF THE INTRAHOSPITAL TRANSPORT}

\section{TIME OF RETURN:}

$\square$ Connection of the patient to the mechanical ventilator

$\square$ Monitoring of the patient

$\square$ Systemic arterial pressure

$\square$ Cardiac frequency

$\square$ Respiratory frequency

$\square$ Oxygen saturation

$\square$ Orotracheal aspiration of the patient if necessary

$\square$ Return of drugs not transported

$\square$ Sedative drugs_— $\square$ increase $\square$ reduction $\square$ unchanged $\square$ starting

$\square$ Vasoactive drugs__ $\square$ increase $\quad \square$ reduction $\square$ unchanged $\square$ starting

$\square$ Recording the IHT in the medical records

$\square$ If adverse events occurred, recording them in the medical records

Thus, in the light of the adoption of the script by other areas - as in the case of aviation - this is presented as a simple and appropriate means for reducing incidents and AEs. In this way, the use of a script must be incorporated by health professionals into clinical practice, as it provides a standardized method for undertaking a safer IHT and enables the team to observe and inspect all the stages which can compromise the safety of the IHT. As a consequence of this, the script can become a checklist, being a strategy for improving the practice of safety in the scenario of the IHT.

\section{CONCLUSION}

The checklist is considered to be an instrument which contributes in the organizing of all the phases of the IHT, in order to reduce the occurrence of incidents and AEs. Due to the high number of AEs, whether through lack of training of the team or through lack of standardization of the actions, checklists are easily accessible, as simple safety measures can be adopted by all the members of the team. It is a way of guaranteeing safe practices for the IHT. It is considered that hospitals need to organize their services so as to promote patient safety through the implementation of checklists. In addition to keeping their professionals trained in relation to the transfer of patients, whether or not the patient has been admitted to ICU, it is necessary to plan and organize a specific service for patient transport.

Emphasis is also placed on the need to verify the effectiveness of the present script for evaluating patients for intrahospital transport for the safety of the patient, and its level of practicality, through its use in varying hospital spaces, such that the same can become a checklist.

\section{REFERENCES}

1. World Health Organization. WHO Patient Safety Health Topic [online]. 2012 [acesso 2012 Nov 08]. Disponível em: http://www.who.int/topics/ patient_safety/en

2. World Health Organization. WHO Patient Safety [online]. 2013 [acesso 2013 Out 29]. Disponível em: http://www.who.int/topics/patient_safety/en/

3. Mello JF, Barbosa SFF. Cultura de segurança do paciente em terapia intensiva: recomendações da enfermagem. Texto Contexto Enferm [online]. 2013 [acesso 2013 Out 30]; 22(4):1124-33. Disponível em: http:/ / www.scielo.br/scielo.php?pid=S010407072013000400031\&script=sci_arttext

4. Ministério da Saúde (BR). Portaria n.529 de 1 abril de 2013 institui o programa nacional de segurança do paciente (PNSP) [online]. Brasília (DF): MS; 2013 [acesso 2013 Jun 1]. Disponível em: http:// bvsms.saude.gov.br/bvs/saudelegis/gm/2013/ prt0529_01_04_2013.html.

5. Vincent C. A evolução da segurança do paciente. In: Vincent C. Segurança do paciente: orientações para evitar eventos adversos. São Caetano do Sul (SP): Yendis Editora; 2009

6. Wachter RM. Compreendendo a segurança do paciente. Porto Alegre (RS): Artmed Editora; 2010

7. Tofolleto MC. Fatores associados aos eventos adversos em unidade de terapia intensiva [tese online]. São Paulo (SP): Universidade de São Paulo, Escola de Enfermagem; 2008 [acesso 2013 Out 30]. Disponível em: http:/ / www.teses.usp.br/teses/disponiveis/7/7139/tde-07052009-112654/pt-br.php

8. Schwonke CRGB, Lunardi Filho WD, Lunardi VL, Santos SSC, Barlem ELD. Perspectivas filosóficas do uso da tecnologia no cuidado de enfermagem em terapia intensiva. Rev Bras Enferm. 2011 JanFev [acesso 2013 Out 30]; 64(1):189-92. Disponível em: http://www.scielo.br/scielo.php?script=sci arttext\&pid=S0034-71672011000100028

9. Zuchelo LTS, Chiavone PT. Transporte intrahospitalar de pacientes sob ventilação invasiva: 
repercussões cardiorrespiratórias e EA. J Bras Pneumo [online] 2009 Abr [acesso 2013 Out 21]; 35(4):367-74. Disponível em: http://www.scielo. br/pdf/jbpneu/v35n4/v35n4a11.pdf

10. Lieshout EJV, Stricker K. Patient transportation: skills and techniques. [s.1.]. European Society of Intensive Care Medicine. 2011.

11. World Health Organization. WHO Patient Safety Checklists [online]. 2014 [acesso 2014 Sep 20]. Disponível em: http://www.who.int/ patientsafety/implementation/checklists/en

12. Haynes AB, Weiser TG, Berry WR, Lipsitz SR, Breizat AH, Dellinger EP. A surgical safety checklist to reduce morbidity and mortality in a global population. N Engl J Med. 2009 Jan 29 [acesso 2013 Out 30]; 360(5):491-9. Disponível em: http:/ / www. nejm.org/doi/pdf/10.1056/NEJMsa0810119

13. Choi HK, Shin SD, Ro YS, Kim do K, Shin SH, Kwak YH. A before and after-intervention trial for reducing unexpected events during the intrahospital transport of emergency patients. Am J Emerg Med [online]. 2012 Oct [acesso 2013 Out 21]; 30(8):143340. Disponível em: http:/ /www.ajemjournal.com/ article/S0735-6757(11)00535-3/abstract\#

14. Réa-Neto A, Castro JEC, Knibel MF, Oliveira MC. Gutis-Guia da UTI segura [online]. São Paulo (SP): Associação de Medicina Intensiva Brasileira; 2010 [acesso 2013 Nov 17]. Disponível em: http:/ / www. orgulhodeserintensivista.com.br/PDF/Orgulho_ GUTIS.pdf

15. Jarden RJ, Quirke S. Improving safety and documentation in intrahospital transport: development of an intrahospital transport tool for critically ill patients. Intensive Crit Care Nurs. 2010 Apr; 26(2):101-7.
16. Zar JH. Biostatistical analysis. $4^{\text {a }}$ ed. New Jersey (US): Prentice-Hall; 1999.

17. Callegari-Jacques SM. Bioestatística: princípios e aplicações. Porto Alegre (RS): Artmed; 2003.

18. $R$ core team. 2013. A language and environment for statistical computing [online]. Vienna (AT): R Foundation for Statistical Computing. [acesso 2013 Nov 17]. Disponível em: http://www.R-project. org/

19. Polit D, Beck CT. Fundamentos da pesquisa em enfermagem: avaliação de evidências para a prática de enfermagem. $7^{\text {a }}$ ed. Porto Alegre (RS): Artmed; 2011.

20. Pereira Júnior GA, Nunes TL, Basile-Filho A. Transporte intrahospitalar do paciente crítico. Medicina. 2007 Ou-Dez; 40(4):500-8.

21. Chang, Y. Lin LH, Chen WH, Liao HY, Hu PH, Chen SF, et al. Quality control work group focusing on practical guidelines for improving safety of critically ill patient transportation in the emergency department J Emerg Nurs. 2010 Mar; 36(2):140-5.

22. Nogueira VO, Marin HF, Cunha ICKO. Informações on-line sobre transporte intrahospitalar de pacientes críticos adultos. Acta Paul Enferm. 2005; 4(18):390-6.

23. Almeida ACG, Neves ALD, Souza LBC, Garcia JH, Lopes JL, Barros ALBL. Transporte intrahospitalar de pacientes adultos em estado crítico: complicações relacionadas à equipe, equipamentos e fatores fisiológicos. Acta Paul Enferm [online]. 2012 [acesso 2012 Nov 14]; 25(3):471-6. Disponível em: http:// www.scielo.br/pdf/ape/v25n3/v25n3a24.pdf

24. MacLenon M. Use of a specialized transport team for intrahospital transport of critically 111 patients. Dimens Crit Care Nurs. 2004 Set-Out; 23(5):225-9. 